\title{
LUONTOKO POLITIIKKAA?
}

YRJÖ HAILA ja VILLE LÄHDE (toim.) Luonnon politiikka. Vastapaino 2003. 267 sivua.

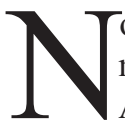
oin 2600 vuotta sitten miletolainen filosofi Anaksimandros kirjoitti kirjan "Luonnosta". Ei tiedetä varmasti, oliko tämä kirjan nimi vai ainoastaan luonnehdinta, ja sen sisällöstäkin tiedetään hyvin vähän. Sen myötä kuitenkin länsimaiseen ajatteluun ilmaantui käsite "luonto", kreikaksi fysis ja latinaksi natura, ja siitä pitäen on lähes herkeämättä pohdittu kysymyksiä luonnon ja ihmisen yhtäläisyyksistä, eroista ja vastakkaisuuksista, luontoa ihmisessä ja ihmistä luonnossa. Eikä pohdinta ole jäänyt pelkästään luonnontieteelliseen selvittelyyn, vaan yhtä paljon ja enemmänkin se on koskenut etiikkaa, ihmisen moraalista merkitystä luonnossa ja luonnon merkitystä ihmisessä. Aineistoa keskusteluun on kertynyt valtavia määriä: pelkästään Robert M. Torrancen muutama vuosi sitten (1998) julkaisema antologia "Encompassing Nature", johon on valittu merkittäviä tekstejä luonnosta ja luontokäsityksistä muinaisuudesta aina 1700-luvun lopulle asti, käsittää 1200 kookasta ja tiheästi ladottua sivua.

Tuntuu siltä että kahden seuraavan vuosisadan teksteistä saisi helpostikin yhtä laajan antologian; ehkä joku sellaisen on jo tehnytkin.

Professori Yrjö Hailan ja maisteri Ville Lähteen toimittama antologia "Luonnon politiikka" on joukko lastuja tämän perinteen suuresta tammesta. Se käsittää kaikkiaan seitsemän kirjoitusta, joista yksi on Hailan ja Lähteen, yksi pelkästään Hailan laatima, ja loput viisi englannista käännettyjä; vanhin näistä on vuodelta 1986 ja uusin vuodelta 2002. (Bruno Latourin essee "Moderni vai ekologinen" on tosin kirjoitettu alun perin ranskaksi, ja suomennoksessakin mainitaan käytetyn ranskankielistä alkutekstiä, mutta olisi kai koko käännös voitu tehdä suoraan ranskasta.) Tämä rakenne tekee kirjasta melko hajanaisen, sillä kirjoittajien taustat ovat varsin erilaiset ja he tuntuvat kirjoittavan eri asioista. Se sinänsä on ymmärrettävää, onhan kirjoitukset poimittu tekijöiden erilaisissa yhteyksissä julkaisemien esseiden joukosta.

Lukijan ei ehkä kannatakaan yrittää selviytyä koko kirjasta kerralla, varsinkin kun tekstit eivät luonnostaan ole keveitä, mutta jos ottaa urakakseen esseen päivässä, niin että voi paneutua rauhassa eri kirjoittajien ajatusmaailmaan, on viikko aivan kohtuullinen lukuaika.

\section{LUONNON JA \\ KULTTUURIN HÄILYVÄ RAJAVIIVA}

Ehkä kiinnostavin kirjan esseistä - ainakin suomalaisen lukijan kannalta - on Yrjö Hailan kirjoitus 'erämaasta' ja ympäristöajattelun moniulotteisuudesta. Olen hiljakkoin eräässä toisessa yhteydessä joutunut toteamaan, miten suomen kielen "erä"-käsitteelle ei ole muissa kielissä yksiselitteisiä vastineita. Meillä erämaa on alkuaan ollut etäistä metsästysmaata, jos- sa "erämiehet" harjoittivat "eränkäyntiä", mutta kuten Hailakin toteaa, sen konnotaatiot ovat muuttuneet sen siirryttyä luonnonsuojelun yhteyteen. Nykyään sitä vastaisi lähinnä englannin wilderness, jolla oli tärkeä sija 1800-luvun amerikkalaisten luonnonsuojelijoiden sanastossa ja 1900-luvun puolella luonnonsuojelun käytännössä; esimerkiksi Wilderness Society perustettiin $1935 \mathrm{ja}$ "erämaalaki", Wilderness Act, säädettiin 1964.

Suomessa erämaalaki on puolestaan ollut olemassa vasta vuodesta 1991, vaikka erämaita tietenkin rauhoitettiin ja luonnonsuojelulaki säädettiin jo 1900-luvun ensi vuosikymmeninä. Haila tarkastelee "villiä" luontoa ja kulttuurin vaikuttamaa luontoa sekä varhaisten amerikkalaisten, kuten Henry Thoreaun, ajattelussa että myöhemmässä luonnonsuojelussa ja päätyy siihen tulokseen, että luonnon ja kulttuurin rajalinjaa ei ole mahdollista määritellä. Ihmisestä ja hänen kulttuuristaan täysin riippumatonta luonnontilaa ei enää ole missään, ja sekin joka pyrkii lyhyemmäksi tai pitemmäksi ajaksi vetäytymään "erämaahan", kantaa kulttuuria kaiken aikaa mukanaan.

Toisaalta on yhä selvempää, että kulttuuri toimii ainoastaan "luonnon", toisin sanoen ympäristön, ehdoilla. "Ehkä asian ydin on siinä, että me emme kykene määrittelemään luonnon ja kulttuurin välistä rajalinjaa siksi, että olemme itse sijoittuneet rajalle."

Luonto on sitä paitsi käsitetty aikojen kuluessa lähes vas- 
takkaisilla tavoilla: luonnon tapahtumat ovat lainmukaisia, ennustettavia, "luonnonlakeja" noudattavia, mutta samalla luonto on jotakin yllättävää, salaperäistä, sananmukaisesti "villiä". Romantiikan perintö iskee valistuksen perintöä vastaan, tässä niin kuin muussakin ajattelussamme! Niinpä Haila huomauttaakin: "Meidän tulisi ymmärtää inhimillisen olemassaolon luonnolliset ehdot siten, että oppisimme läpikäyvästi kunnioittamaan perustanamme olevia villejä, heterogeenisia, spontaaneja, hallitsemattomia ja hallitsemattomina pysyviä aineksia - ja samalla niihin aina sisältyviä uutuuden mahdollisuuksia."

Tähän liittyy kiinnostavalla tavalla Raymond Williamsin essee luontokäsityksistä, jossa tosin tarkastellaan lähinnä vain englantilaisten kirjailijoiden käsityksiä luonnosta ja luonnontilasta, kokonaan sivuuttaen vaikkapa Montesquieu, Rousseau ja muut ranskalaiset valistusajattelijat ja esiromantikot, joiden ajattelussa kuvitellulla "luonnontilalla" oli hyvinkin suuri merkitys. Myös saksalainen kirjallisuus, jossa "luontoa" ja "kulttuuria" on pohdittu hyvinkin paljon, tuntuu tässä kokoelmassa loistavan poissaolollaan. Kenties jonkun saksalai- sen kirjoittajan löytäminen mukaan olisi monipuolistanut kirjaa, ja vastaavasti Donna Harawayn - ainakin tämän kirjoittajalle - käsittämättömäksi jäävän ja sekavan "Manifestin kyborgeille" olisi voinut jättää pois. Omalla tavallaan turhalta tuntuu myös William E. Connollyn "Ääniä tuulispäästä", jossa käsitellään yhtäältä Jobin kirjaa ja toisaalta 1800 -luvulla elänyttä ranskalaista hermafrodiittia Alex/inaa, sillä näiden yhteys luontokäsityksiin jää kovin epäselväksi eikä heillä tunnu olevan muuta yhteistä nimittäjää kuin kärsimys sinänsä. Sekin jää kyseenalaiseksi, Jobin kärsimys kun on fiktiota ja Alex/inan ilmeisesti ei, ja kärsimysten aiheetkin ovat kovin erilaisia.

\section{LUONTOPOLITIIKKA, IHMINEN JA LUONTO}

Kun ihmisen ja luonnon tai luonnon ja kulttuurin jyrkkä erottaminen ei ole mahdollista, kulttuurin ja luonnon suhteesta ei voi olla olemassa "kokonaisteoriaa". Tässä Haila on epäilemättä oikeassa, jos kohta voidaan kysyä, onko joku pyrkinyt tällaista teoriaa laatimaankaan. Samoin voidaan kysyä, onko luontoa kuitenkaan syytä "politisoida", tehdä siitä ikään kuin poliittista toimijaa, vaikka
Haila ja Lähde väittävätkin, että "luonnon politisoituminen tulee ilmi moninaisissa muodoissa." "Luonnon poliittisuus on sitä, että luonto on osallisena inhimillisten yhteisöjen mahdollisuuksien muovautumisessa", he selittävät, ja heidän mielestään "on oikeutettua sanoa, että myrskyt tekivät Suomessa politiikkaa”, koska syksyn 2001 myrskyt vaikuttivat poliittiseen keskusteluun ja lainsäädäntöönkin. Mieleen tulee 1970-luvulla usein toisteltu väite "kaikki on politiikkaa". Omasta puolestani jättäisin kyllä myrskyt politisoimatta, jotta "politiikan" käsite ei karkaisi aivan yli äyräidensä, ja säilyttäisin "ympäristöpolitiikankin" ympäristöön kohdistuvana, ei "ympäristön harjoittamana" politiikkana.

Tärkeintä ehkä onkin, että Haila ja kumppanit saavat lukijansa miettimään luonnon, ihmisen ja kulttuurin suhteita ja kenties myös huomaamaan, että sellainen "moderni" ajattelu, jossa ihminen ja luonto on jyrkästi erotettu toisistaan, alkaa politiikankin kannalta - olla aikansa elänyttä. Pelkkä joidenkin erämaiden rauhoittaminen "kulttuurin" ulkopuolelle ei todellakaan enää riitä!

\section{Anto Leikola}

